\title{
CÂTEVA DETALII CONSTRUCTIVE ALE CLISIARNIțEI MĂNĂSTIRII Probota (Jud. SucEAVA)
}

MONICA DEJAN

ŞTEFAN DEJAN

\section{REZUMAT:}

În ultimii 50 de ani, numeroase cercetări arheologice au fost realizate la mănăstirea Probota (jud. Suceava). Cele mai importante au început în anul 1994 și s-au încheiat în 2000, fiind parte a proiectului de restaurare al întregului ansamblu. Ulterior, câteva lucrări edilitare efectuate în incinta mănăstirii au fost precedate de noi cercetări arheologice, care au permis observarea unor detalii constructive legate de istoria Turnului Tezaur (situat în partea de nord-vest a mănăstirii) și de starea sa de conservare actuală.

\section{Abstract: Some Construction Details of the Treasure Tower (Clisiarniţă) From the Probota Monastery (Suceava county).}

In the last 50 years, a lot of archaelogical researches were made in the Probota Monastery (Suceava county). The most important researches started in 1994 and ended in 2000, as part of the restauration works made in the entire monastery. In time, some landscaping works in the monastery were preceded by new archaeological researches, which were very useful to observe construction details significant for understanding the history of the Treasure Tower (situated in the North-West part of the monastery) and its present conservation conditions.

CUVINTE CHEIE: Mănăstirea Probota, Clisiarniţă, cercetări arheologice, detalii constructive

KEYWORDS: Probota Monastery, Treasure Tower, archaeological researches, construction details

Mănăstirea Probota cu Biserica Sfântul Nicolae (jud. Suceava) reprezintă unul din cele mai importante ansambluri eclesiastice din Moldova medievală. Însemnătatea sa este legată atât de vechime, cât şi de personalităţile istorice îngropate aici, în principal cele aparţinând familiei lui Petru Rareş, domnul Moldovei, dar şi al sfetnicilor acestuia. Biserica adăposteşte şi piatra de mormânt a doamnei Oltea, mama lui Ştefan cel Mare.

Prima menţiune documentară a existenţei unui lăcaş de cult la Probota datează din anul 1398. Suretul după documentul emis de Ștefan I, domnul Moldovei, menționează dania a două sate situate pe pârâul Pobrata, mănăstirii Sfântul Nicolae care este în Poiană ${ }^{1}$. Deși copiile păstrate ale documentului original sunt mult mai târzii, ele atestă existența acestui lăcaș la sfârșitul secolului XIV. Precizăm că în cele două Pomelnice ale mănăstirii, cel datat în anul $1781^{2}$ şi cel datat în anul $1823^{3}$, anul de fondare a primei mănăstiri este 1391, deşi aici apare o incertitudine pentru că în acel an domnea Petru I şi nu Ştefan I I. În deceniul opt al secolului trecut (1973) au fost realizate cercetări arheologice care au dezvelit ruinele unei biserici datată în a doua jumătate a secolui XV ${ }^{5}$. Menționăm că, în acest moment, nu se cunoaște locația primei biserici ,din Poiană”, cea construită la sfârșitul secolului XIV și pomenită în documentul din $1398^{6}$. Existenţa a trei mănăstiri succesive (fără a fi situate însă în acelaşi loc) la Probota este menţionată în Pomelnicul din anul 1791: Petru Rareş ... „a zidit a treia mănăstire, ce este şi acum”, dar şi în cel din $1823^{7}$. Informațiile despre celelalte componente ale mănăstrii sunt disparate, iar primele imagini publicate datează din anul 1909 (Fig. 1).

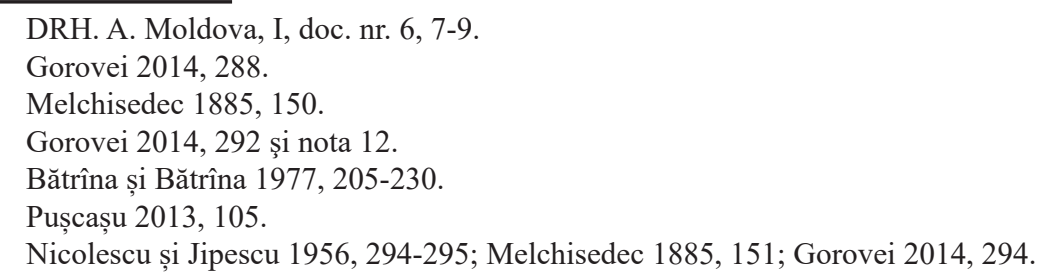




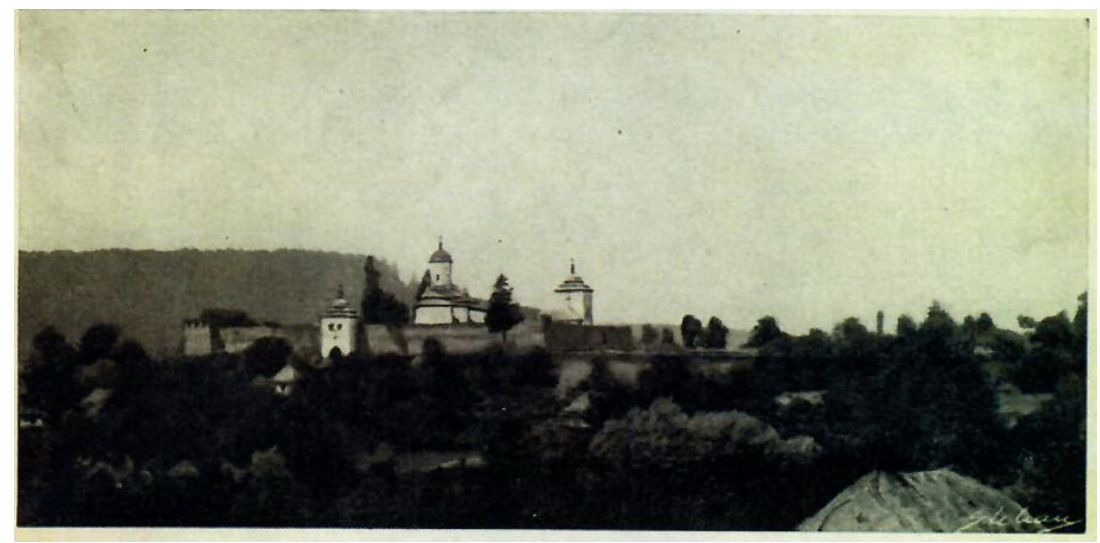

Fig. 1. Mănăstirea Probota în anul 1909: turnul de la intrare, biserica și turnul clopotniță (după Ghika-Budești, Balș 1909)

Actuala biserică având hramul „Sfântul Nicolae” a fost ridicată (conform pisaniei) în anul 1530 de către Petru Rareș, domnul Moldovei, deși lucrările s-au încheiat la o dată ulterioară, după cum au arătat cercetările arheologice. Destinată să fie necropolă voievodală, biserica va adăposti mormintele lui Petru Rareș și al soției sale, Elena, precum și ale altor membri ai familiei domnitoare și ale unor boieri. De altfel, actul de închinare al mănăstirii către Biserica Sfântului Mormânt de la Ierusalim (1677) conține la început și un scurt istoric al lăcașului în care sunt precizați cei ale căror morminte se află în biserică $\breve{p}^{8}$. Actul de închinare menţionează momentele dificile prin care a trecut mănăstirea la începutul secolului XVII: "pre vremea văleatului 7130 [1622] să stricase obiceaiul cel bun a sf. mănăstiri intratâta, cât călugării cei răi au băgat tâlharii de-au jăcuit toată averea boiarilor ţării din vistiarul mănăstirii de i-au sărăcit şi de atuncea au stâtut mănăstirea urâtă tuturor şi nime n-au mai căutat de nevoia ei şi o au aprins cu betiale de-au ars aceea sf. mănăstire ce da cuviinţă la toată ţara" . Mănăstirea a avut parte de-a lungul timpului de transformări ulterioare secolului XVI, între care cele mai importante s-au petrecut în timpul domniei lui Vasile Lupu care reface zidul înconjurător ridicat de Elena Doamna şi fiii Iliaş, Ştefan şi Constantin. Mechisedec, episcopul Romanului, notează pisania pe care o vede la Probota și care astăzi nu se mai păstrează, prin care se marca încheierea lucrărilor realizate la porunca domnitorului Vasile Lupu (1646) după ce acesta a văzut „,̂nvechite lucrurile mănăstirii” ${ }^{\prime 10}$. Având calitatea de ctitorie domnească, lipsa unei inițiative a domnitorilor ulteriori de a realiza reparații, nu a permis unor boieri să aibă inițiative în acest sens ${ }^{11}$. $\mathrm{Cu}$ acceptul domnitorului, postelnicul Iorgu va înlocui acoperişul trapezei ${ }^{12}$. În anul 1664, hatmanul Gheorghe Coci promisese că va repara chiliile şi celelalte construcţii de piatră din preajma bisericii, deşi lucrările sunt începute, ele nu sunt finalizate, ceea ce a accelerat degradarea: "s-au răsăpit şi chelăriile şi magherniţa" viețuitor al mănăstirii, Dosoftei, mitropolit al Moldovei, relatează evenimentele petrecute pe parcursul secolului XVII, amintind şi contribuţia sa la refacerea lăcaşului: „... am eliberat monastirea de toţi creditorii săi, am săvârşit edificiile şi trapeza şi am ridicat tot ce era în ruine ..."14

Deşi mitropolitul Dosoftei, a dorit prin actul de închinare al mănăstirii către Sfântul Mormânt să îi crească statutul şi să o protejeze, efectul a fost contrar ${ }^{15}$. Pe parcursul secolului XVIII, stareții vor încerca să oprească distrugerea treptată a mănăstirii, dar se fac doar lucrări de mică întindere cu materiale de proastă calitate, iar o parte din clădirile din zona de sud a bisericii încep să se ruineze ${ }^{16}$.

Un izvor remarcabil pentru istoria Probotei îl reprezintă Pomelnicul scris la mănăstire. Deşi lipseşte numele lui Vasile Lupu, care a fost un important binefăcător, toate celelalte nume dovedesc bunăvoinţa constantă a domnilor moldoveni faţă de acest venerabil aşezământ monahal, prin daniile pe care aceştia le fac. Ultimul domnitor moldovean amintit ca binefăcător al mănăstirii este Constantin Mavrocordat, dar această ultimă pomenire are legătură cu încheierea primei forme a documentului, probabil înainte de 1769, când acesta moare ${ }^{17}$.

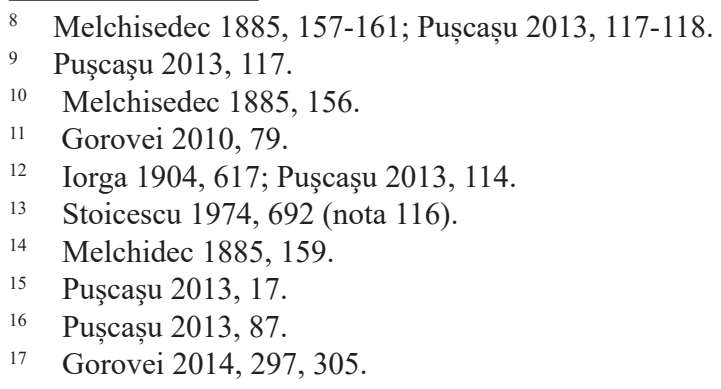


Ocuparea Moldovei de Nord de către austrieci a însemnat o complicare a situaţiei mănăstirii care avea proprietăţi rămase dincolo de "cordon" şi pentru care arhimandriţii de la sfârşitul secolului XVIII fac intervenţii la noua autoritate ${ }^{18}$. Pe parcursul secolului XIX sunt menţionate intervenții la monument, cum ar fi înlocuirea acoperişului bisericii din anul $1835^{19}$. Secularizarea averilor mănăstirești va schimba statutul ansamblului, dar nu îi va îmbunătăți condiția. Melchisedec, episcopul Romanului, vizitează Probota în anul 1879 şi consemnează: ,astăzi Mănăstirea Probota reprezintă o ruină. Casele egumeneşti foarte mari şi cu trei etaje au căzut în ruină’’20. În 1909, N. GhikaBudeşti şi G. Balş amintesc de un incendiu recent care a distrus casele egumenului (Fig. 2) ${ }^{21}$.

Planul de situafie.

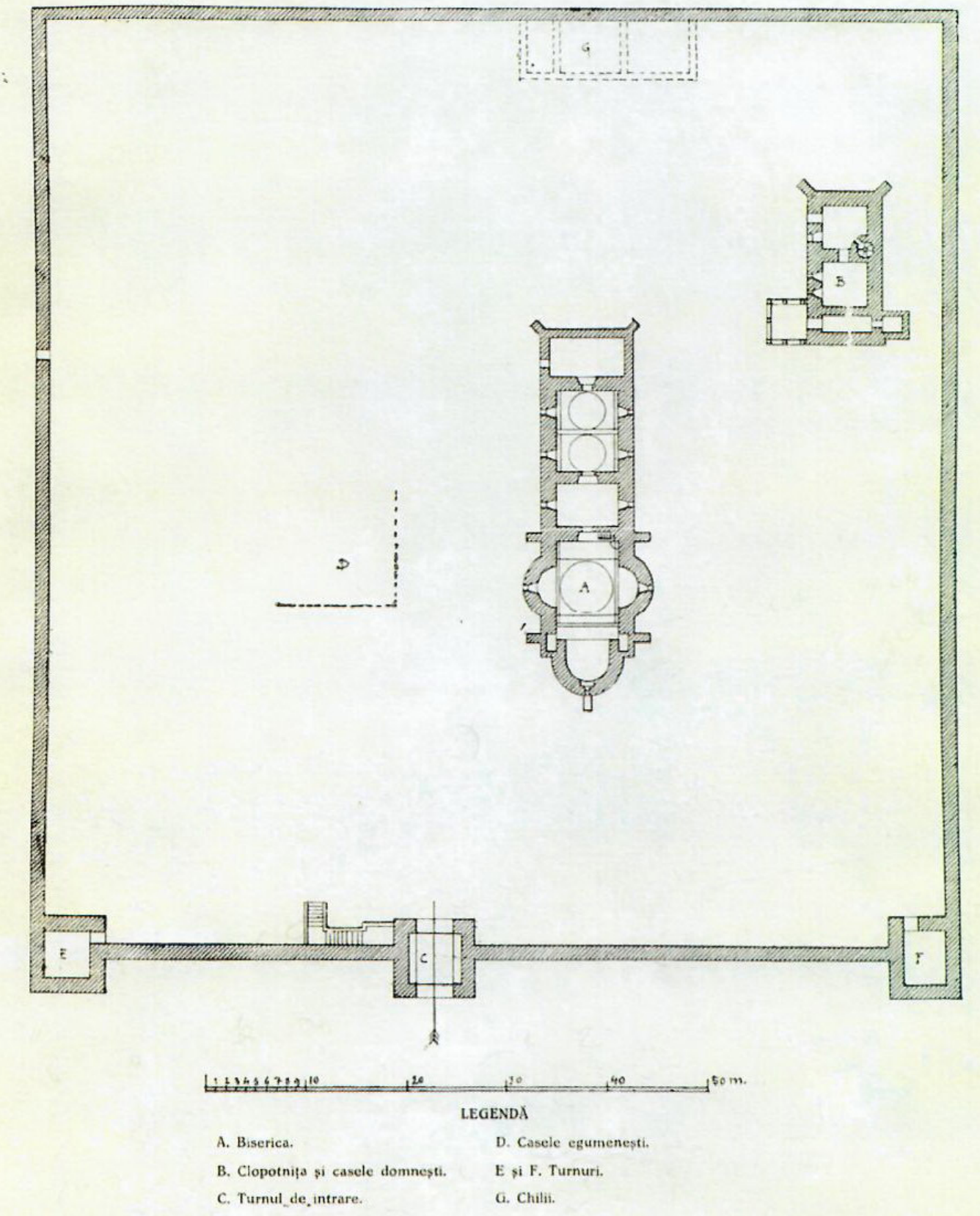

Fig. 2. Ansamblul mănăstiresc Probota cu elementele componente în anul 1909 (după Ghika-Budești, Balș 1909)

\footnotetext{
8 Balan 1939, 29.

Stoicescu 1974, 692 (nota 117).

Melchisedec 1885, 169.

${ }^{21}$ Ghika-Budeşti și Balş 1909, 10.
} 
Actele Consistoriului Superior Bisericesc din anul 1913 consemnează intervenția arhimandritului Teoctist Stupcanu care aducea la cunoștința Consistoriului următoarele: „de la secularizare nu s-a făcut nicio reparație, astfel că în biserică plouă, iar din cauză că nu are nicio sobă cu foarte mare greutate se poate face slujbă iarna, fiind ferestrele sparte. De asemenea, in curtea fostei mănăstiri se găsește o casă căreia dacă $i$ s-ar face o mică reparație s-ar putea locui de paroh, care nu are locuință proprie in parohie. Pentru aceste motive, cu onoare vă propun și cu smerenie rog, a se interveni către Onor. Cassa Bisericei, să se acorde un fond, pentru facerea a două sobe în biserică, reparația ferestrelor bisericii și reparația casei parohiale din incinta mănăstiriił"22.

Dacă în anul 1908, mănăstirea este martora unor manifestări patriotice prilejuite de așezarea pietrei de mormânt a Doamnei Oltea în Biserica Sfântul Nicolae ${ }^{23}$, după primul război mondial sunt întreprinse măsuri pentru a ameliora starea de conservare a lăcașului și a zonei înconjurătoare: se înlocuiește acoperișul bisericii, se realizează lucrări la uși și ferestre, se înlocuiesc ancadramentele deteriorate ${ }^{24}$. Aceste lucrări vor fi continuate și după cel de-al doilea război mondial, când se constată necesitatea de a se interveni asupra zidului de incintă, a clopotniței și a caselor domnești. În 1951 sunt menţionate reparaţii în preajma casei domneşti (adică a clisiarniţei), când se realizează o primă săpătură de jur împrejur ${ }^{25}$. Cu ocazia unor lucrări efectuate în anul 1952 în zona de nord vest a incintei au apărut oseminte și diverse obiecte ${ }^{26}$. În anul 1968, mănăstirea beneficiază de lucrări de restaurare la zidul de incintăa $\breve{a}^{27} \mathrm{Cu}$ ocazia cercetărilor arheologice la ruinele bisericii Probota Veche începute în anul 1973, în anul 1977 arheologii Lia și Adrian Bătrîna au realizat câteva sondaje în zona de est a incintei mănăstirii ridicate de Petru Rareș care au rămas inedite ${ }^{28}$.

Cercetările arheologice desfăşurate între 1994 şi $2000^{29}$ au adus informaţii esențiale cu privire la etapele de construcție ale ansamblului la care se adaugă un patrimoniu arheologic remarcabil provenind în principal din cercetările efectuate la Biserica Sfântul Nicolae. În anul 1994 se realizează cercetări în imediata apropiere a clisiarniței, dar acestea au urmărit posibilitatea existenței unor legături stratigrafice între biserică și zidul de incintă (Fig. 3).

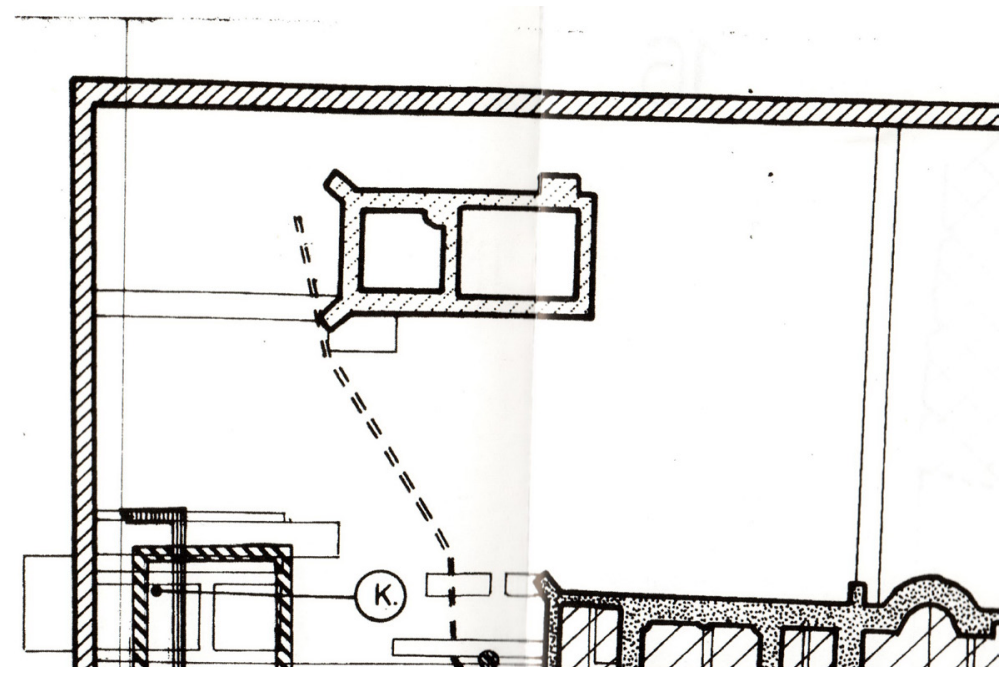

Fig. 3. Cercetările arheologice în zona clisiarniței, campaniile 1994-2000 (după Pușcașu 2013)

În zonă s-au descoperit mai multe pavaje și urmele unor construcții succesive datate între prima jumătate a secolului XVI și secolul XVII ${ }^{30}$. Cercetările arheologice, parte a complexului proiect de restaurare International Support for Restauration and Preservation of the Probota finanţat de Japan Trust Found sub patronaj UNESCO între anii 19962001, s-au concentrat în principal la biserică, dar și în zona ruinelor situate în partea de sud a bisericii, clisiarniţa și zidul de incintă oferind informații prețioase cu privire la acest ansamblu de primă importanță a artei moldovenești şi îmbogățind patrimoniul nostru cu piese de valoare excepțională ${ }^{31}$. Acestea au fost cele mai complexe şi complete cercetări efectuate la Probota, deși ulterior se vor mai realiza supravegheri arheologice sau cercetări preventive datorate unor lucrări edilitare și amenajări peisagistice efectuate în interiorul incintei mănăstirești, ele au fost de mică întindere și în principal în puncte deja epuizate arheologic. O astfel de cercetare a fost realizată în anul 2019 şi ne-a permis unele observații cu privire la modul de construire al turnului din partea de nord-vest și la soluțiile tehnice folosite pentru ridicarea acestuia.

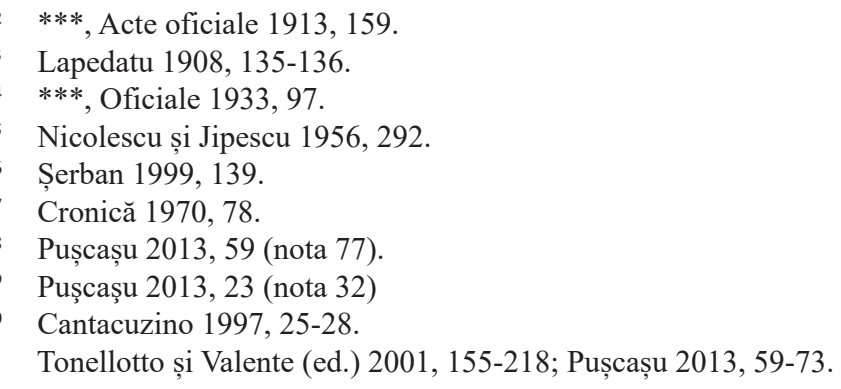


În cadrul ansamblului mănăstiresc, biserica reprezenta punctul central, mai ales dacă se are în vedere că urma să fie o necropolă domnească. Totuși celelalte construcții aveau fiecare importanța lor, iar edificarea lor în etape ulterioare ridicării bisericii, dovedește necesitatea de a acoperi și alte aspecte din viața de obște, în afară de cele strict religioase: chiliile, zidul de incintă, turnul tezaur etc. Toate aceste construcții au apărut păstrându-se preocuparea pentru estetica întregului ansamblu și au fost refăcute periodic, puține păstrând forma lor inițială $\breve{a ̆}^{32}$. Analizarea atentă a relațiilor stratigrafice dintre diversele urme de construcții, pavaje, diverse amenajări și biserică, la care s-au adăugat informațiile documentare, a permis stabilirea mai multor etape în edificarea ansamblului mănăstiresc şi a elementelor sale componente: în prima etapă a fost edificată biserica (în timpul domniilor lui Petru Rareș), pentru ca într-o a doua etapă să fie ridicate zidul de incintă cu turnul de intrare, clisiarnița și câteva construcții din zona sudică a incintei (a doua jumătate a secolului XVII). Ultimele două etape corespund secolului XVII, respectiv secolelor XVIII-XIX ${ }^{33}$.

Clisiarnița sau turnul tezaur prevăzut cu o clopotniță, a fost considerat a fi fost construit în etapa a doua, după anul 1591 (conform datării propuse de către Voica Maria Pușcașu), pe baza unor argumente stratigrafice, dar și a existenței unei conducte de aducțiune a apei, contrafortul de sud-vest al clopotniței păstrând funcționalitatea acesteia $^{34}$. O ipoteză mai veche îi conferea acesteia rol de casă domnească (N. Ghika-Budești, G. Balş şi apoi, Corina Nicolescu $)^{35}$, dar această destinaţie ar putea fi considerată puţin viabilă, având în vedere existența clopotniței în partea superioară. Totuşi, nu excludem această posibilitate, măcar pentru perioade restrânse de timp, când restul construcţiilor din incintă erau în construcţie sau, din contra, se găseau într-o stare avansată de degradare, cum s-a întâmplat pe parcursul secolului XIX şi începutul secolului XX.

Aspectul exterior al turnului de nord-vest este simplu, cu decoraţii minime astăzi (Fig. 4). Forma acestuia este dreptunghiulară împărţită în două compartimente: primul are la etaj clopotniţa care comunică printr-o scară de

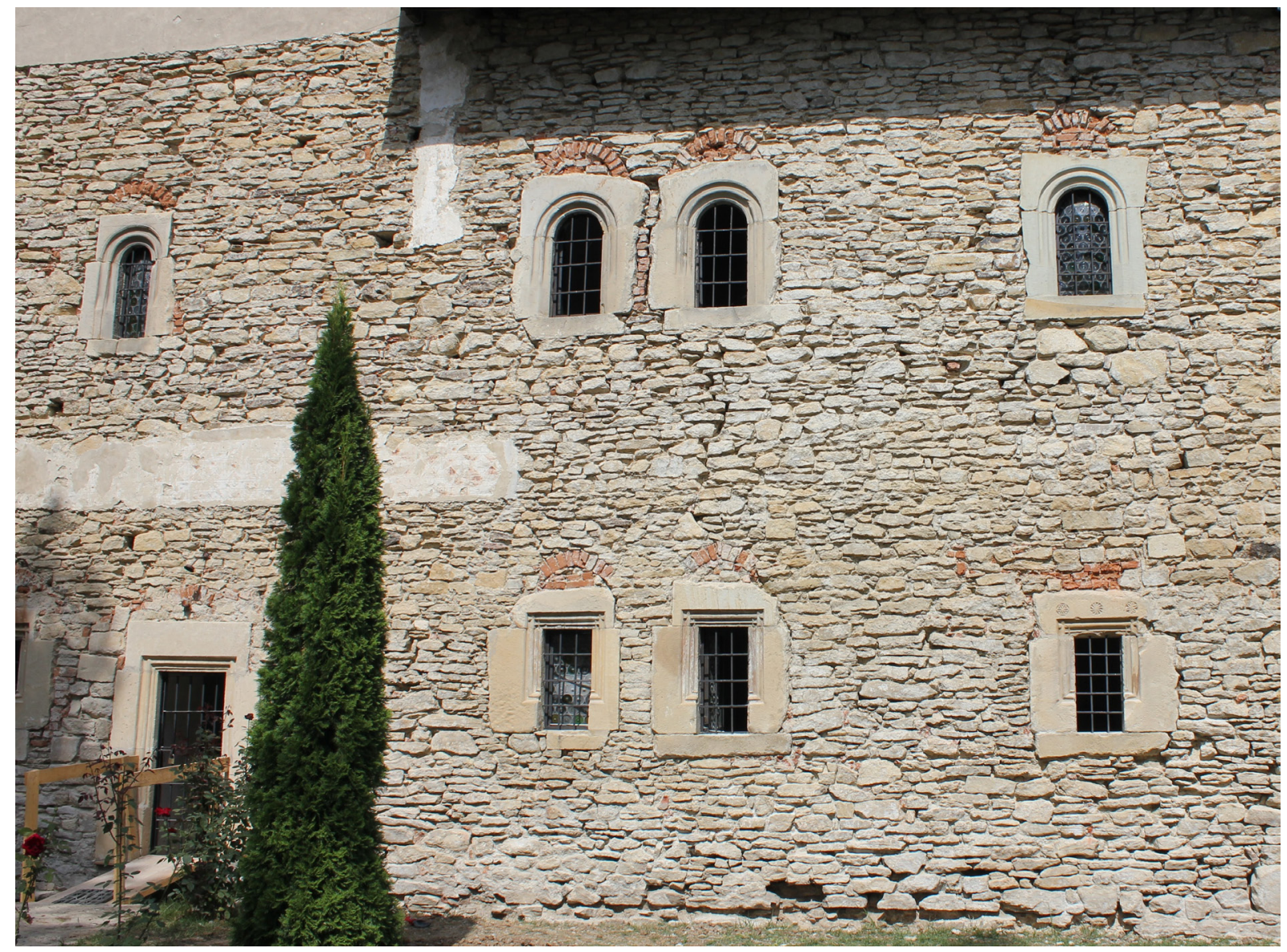

Fig. 4. Elemente de decorație a ferestrelor pe fațada sudică a turnului clopotniță

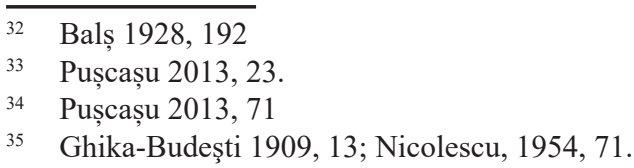


piatră cu parterul, al doilea are la parter şi la etaj două încăperi de mici dimensiuni. Ferestrele de jos ale clisiarniței sunt dreptunghiulare, cu baghete încrucişate întoarse spre exterior. Una dintre ferestre are în partea superioară o decoraţie din trei rozete, asemănătoare cu cele care decorează mobilierul din lemn aflat în interiorul bisericii ${ }^{36}$. Deasupra lor, se găsesc alte ferestre, de dimensiuni mai mici, semicirculare în partea superioară ${ }^{37}$. Construcția prezintă o decorație gotică simplă la ușă și la ferestre, iar zidurile mai păstrează urme ale unei picturi, în zone foarte restrânse. Aspectul zidurilor dovedește existența unor intervenții de-a lungul timpului, care au modificat construcția, în funcție de diversele destinații pe care le-au primit încăperile componente. De asemenea, tăierea în două şi refolosirea pietrei de mormânt a lui Dumşa postelnic, nepotul de soră al lui Ştefan cel Mare, mort în anul 1500, pentru intrarea în clisiarniţă, piesa fiind demontată în anii ‘70 ai secolului trecut ${ }^{38}$, dovedeşte pierderea în timp a informaţiilor cu privire la istoria locului.

Lucrările sesizabile la celelalte edificii din cadrul mănăstirii s-au realizat și la turnul-tezaur care, o dată cu decăderea mănăstirii și evenimentele petrecute în anul 1622, nu mai adăpostea lucruri valoroase, totuşi rolul acestuia rămâne important, aspect dovedit de faptul că este singura construcție, cu excepția bisericii, ajunsă până astăzi, cu toate transformările suferite pe parcurs. Probabil că rolul de clopotniță al acestui turn a necesitat de la început o construcție robustă care, deși a avut vicii destul de importante, i-au asigurat supraviețuirea.

În mod evident, acoperișul a fost înlocuit cândva, la sfârşitul secolului XIX sau în primii ani ai secolului XX, având în vedere că lucrarea lui Ghika Budeşti şi Balş, apărută în 1909, are fotografii cu aspectul acoperişului în forma în care se găseşte şi astăzi (Fig. 5).

Cercetarea arheologică preventivă s-a concentrat în zona clisiarniţei care este situată în colțul de nord vest al incintei fortificate a mănăstirii. Zona nordică a incintei a fost mai puțin cercetată arheologic fiind realizată o singură secțiune în anul 1999. În zona clisiarniţei s-au realizat două secțiuni: prima secţiune realizată în anul 1994 a încercat stabilirea unei relații între peretele nordic al clisiarniţei şi zidul de incintă, iar a doua s-a realizat în anul 2000 în colțul de sud vest al acesteia fiind prelungită până în zidul vestic al incintei. O observație făcută în această parte a incintei este că zona de nord-vest se află la nivelul cel mai înalt având în vedere că panta terenului curge de la vest la est. Pentru reducerea acestei pante, periodic s-au realizat răzuieli ale terenului care au distrus depunerile anterioare. Aceste operațiuni de reducere a pantei terenului s-au realizat ținând cont
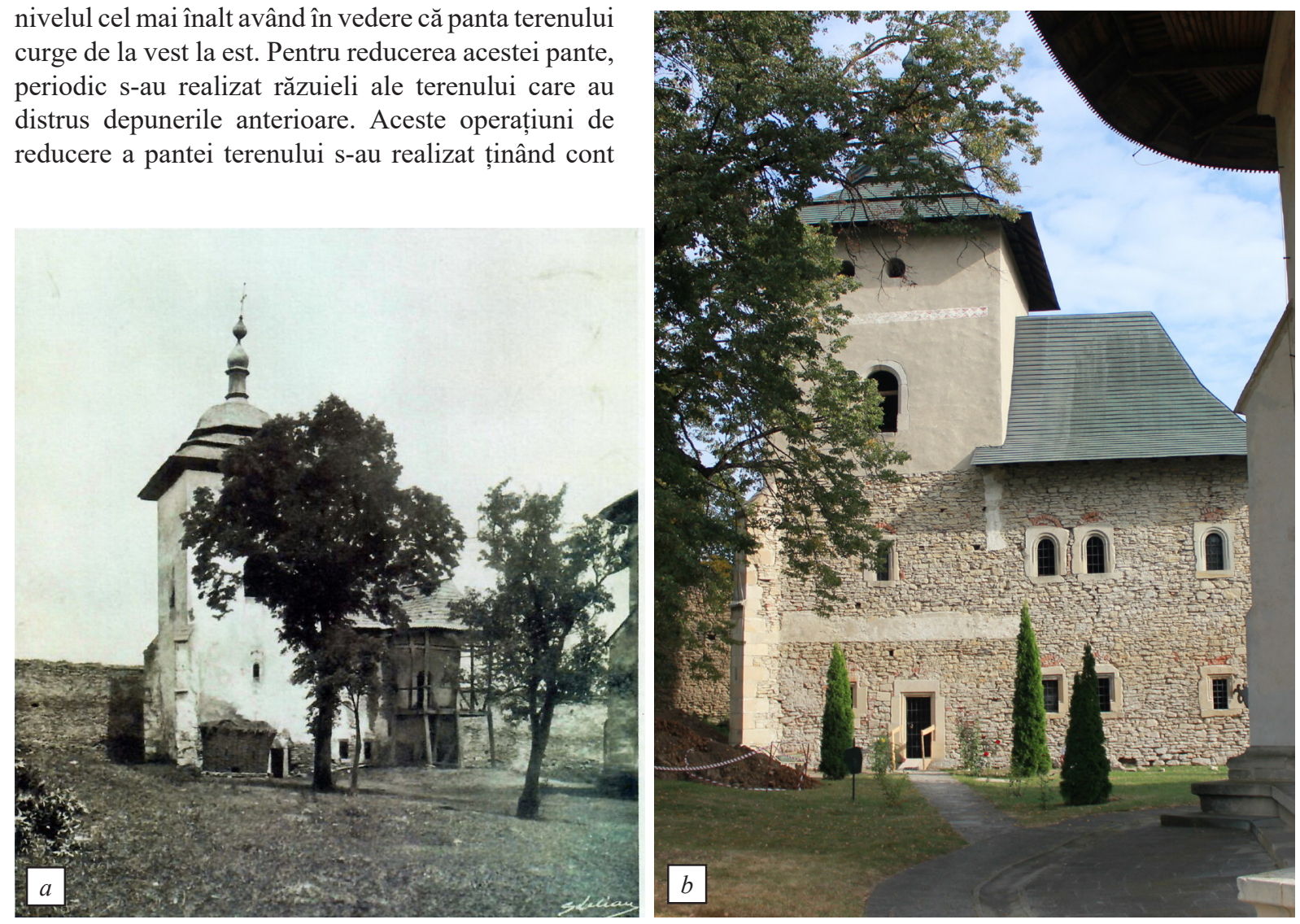

Fig. 5. Clisiarniţa Mănăstirii Probota a-1909 după Ghica-Budeşti, Balş, 1909, b-2019

Ghika-Budeşti 1909, 35-37.

Balș 1928, 246, 254.

Iorga 1905, 61-62; Puşcaşu 2013, 101. 
de scurgerea apelor pluviale de la vest la est ${ }^{39}$. O analiză a primelor fotografii ale clisiarniţei publicate de către N. Ghika-Budeşti şi G. Balş, ne arată că nivelul de călcare la începutul secolului XX era mult mai sus (cu cel puţin jumătate de metru), intrarea în turn realizându-se printr-o treaptă care cobora spre intrare ${ }^{40}$. Ulterior cercetărilor realizate de Voica Maria Puşcaşu, a fost efectuată în anul 2007 o supraveghere arheologică de mică întindere, coordonată de Florin Hău (Muzeul Bucovinei Suceava), care a afectat doar stratul vegetal pentru realizarea unui dren şi a amenajării unei alei de jur-împrejurul clisiarniţei.

În anul 2018 cu ocazia noilor lucrări de restaurare a fost necesară dezvelirea fundațiilor clisiarniţei având în vedere existența unor fracturi în zidurile construcţiei pe latura de sud şi pe cea nordică. Ulterior lucrărilor de restaurare încheiate în anul 2000, în clisiarniţă a fost amenajat un mic muzeu care adăpostea obiecte descoperite în timpul cercetărilor arheologice, precum şi câteva obiecte liturgice aflate în inventarul mănăstirii. Acest muzeu a fost dezafectat datorită umidității excesive din încăperi care nu a putut fi înlăturată şi care afecta integritatea pieselor expuse. Şi această situație trebuia analizată şi în măsura posibilităților eliminată. Mai întâi s-au desfăcut rigolele din jurul clădirii după care s-a trecut la săparea manuală a șanțului. Adâncirea săpăturii până la $-1,98$ m, unde se găsea talpa fundației zidului vestic, nu a oferit nici un fel de date arheologice. Aici se găsea doar un strat de pământ galben purtat, fără materiale arheologice. În acest moment nu putem să ne pronunțăm în privința momentului în care a fost depus acest strat de pământ galben, având în vedere că aici s-au realizat mai multe intervenții prin care s-au realizat lucrări de restaurare a construcţiei $(1934-1938,1951,1968)$.

$\mathrm{Cu}$ toate că intervențiile anterioare au distrus toate eventualele depuneri arheologice, s-au putut face totuși câteva observații cu privire la modul de construire a clisiarniţei şi a soluțiilor constructive adoptate de zidarii care au ridicat-o spre sfârșitul secolului XVI. Diferența între elevație şi fundație este marcată de un rând de pietre așezate orizontal marcând probabil existența unui pavaj în zonă care nu s-a mai păstrat. Deși pe latura de vest fundația are o adâncime apreciabilă, de aproape $2 \mathrm{~m}$, aceasta suportând greutatea turlei clopotniță, este neîngrijit lucrată, mortarul folosit de constructori s-a distrus, rămânând doar piatra. Situația este favorizată şi de înclinarea naturală a terenului de la vest spre est, apele pluviale pătrunzând în fundația zidului vestic prin această zonă (Fig. 6).

În timp, friabilitatea fundațiilor a dus la o umezeală excesivă în interior. În acest fel s-a încercat izolarea fundațiilor cu pământ galben probabil în timpul uneia dintre restaurările anterioare. Existența stratului de pământ galben purtat a fost constatat în jurul construcţiei, astfel stratigrafia existentă în acest moment se reduce la stratul vegetal

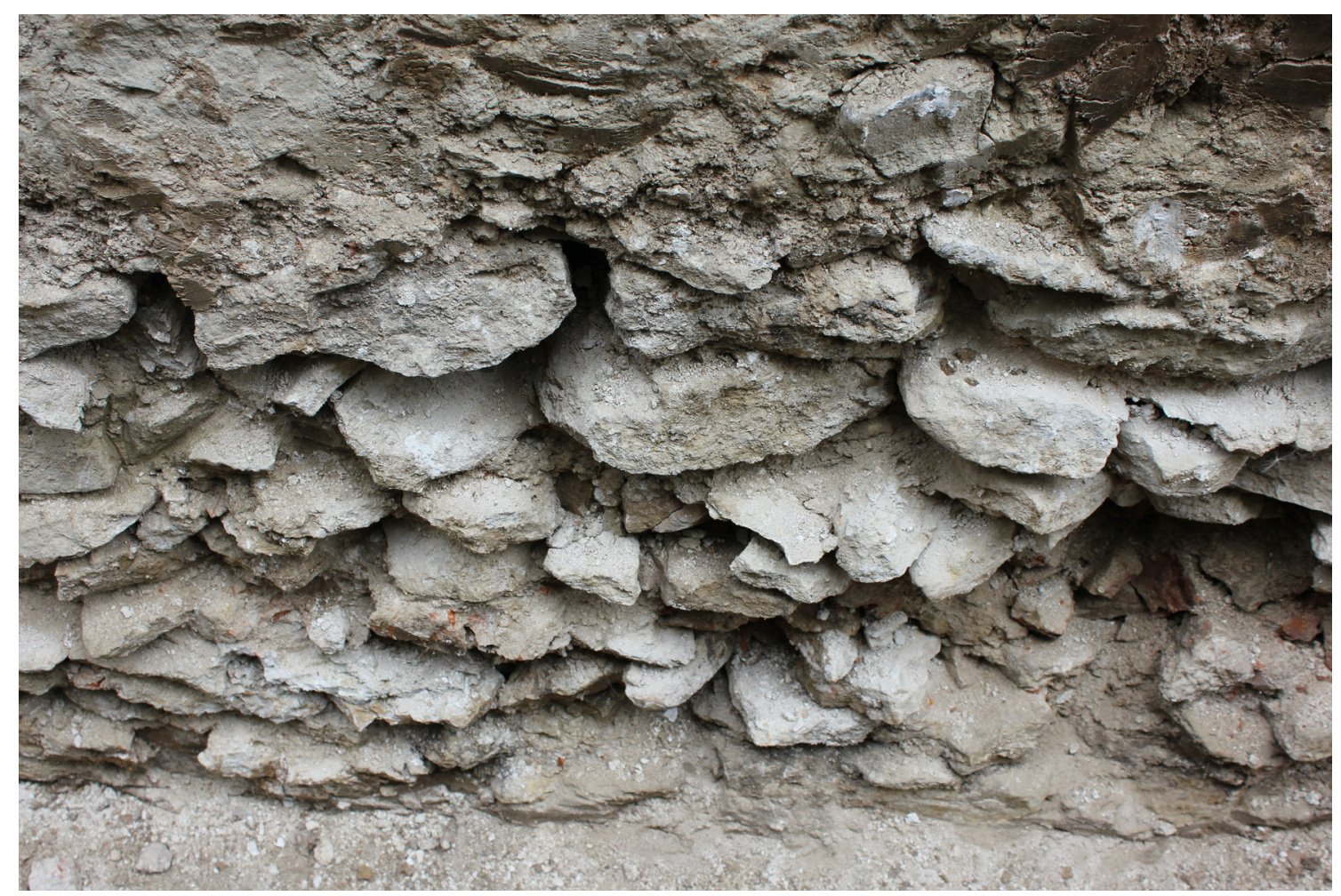

Fig. 6. Aspectul fundației pe latura de vest

\footnotetext{
39 Pușcaşu 2013, 24, 26.

40 Ghika-Budeşti și Balş 1909, 14.
} 
contemporan şi stratul de galben purtat fără urme arheologice. Este evident că numeroasele intervenții, deși au fost făcute cu scopul de a ameliora fisurile apărute în structura de rezistență, nu au avut ca urmare decât agravarea acestor probleme care au produs friabilizarea fundațiilor şi fracturarea zidurilor pe sud și pe nord. Alegerea constructorilor de a realiza o structură cu diferență de nivel a fost inadecvată și pentru că nu ținea cont de înclinarea naturală a terenului de la vest la est, partea care susține clopotniţa având efect de împingere asupra structurii estice, deja mai fragilă din cauza fundaţiei mult mai mici. La acestea adăugăm umiditatea excesivă constatată în încăperile de la parter, până la o înălţime de aproximativ un metru (Fig. 7).

Clisiarniţa are doi contraforţi oblici așezați pe peretele vestic, care au rolul de a prelua din greutatea clopotniței. La baza lor există un decroș: fundația este mai lată decât contrafortul propriu zis cu $0,15 \mathrm{~m}$. Pe latura de sud s-a realizat un șanț cu lăţimea de 0,90 m în care s-a păstrat un martor de $1 \mathrm{~m}$ în dreptul intrării. Aici adâncimea este de 1,85 $\mathrm{m}$ existând o treaptă unde adâncimea fundaţiei ajunge la 0,60 m. Această treaptă se găseşte la 2,25 m est faţă de intrare. Existența unei trepte în fundație a produs fractura zidului în zona acesteia. Constructorii au considerat probabil suficientă existența unei fundații adânci pentru clopotniță care este mai înaltă decât restul construcţiei şi au preferat o variantă mai puțin adâncă pentru partea din construcție care era mai joasă. Pentru laturile de sud şi nord construcția păstrează aceeaşi adâncime de $0,60 \mathrm{~m}$ pentru partea de construcție mai joasă fiind din nou adâncită cu treaptă în zona clopotniței. Toată zona cercetată este afectată de intervenții contemporane fiind realizate șanţuri pentru cablurile electrice, paratrăsnet şi scurgerea pentru un canal colector. În colțul de nord est a

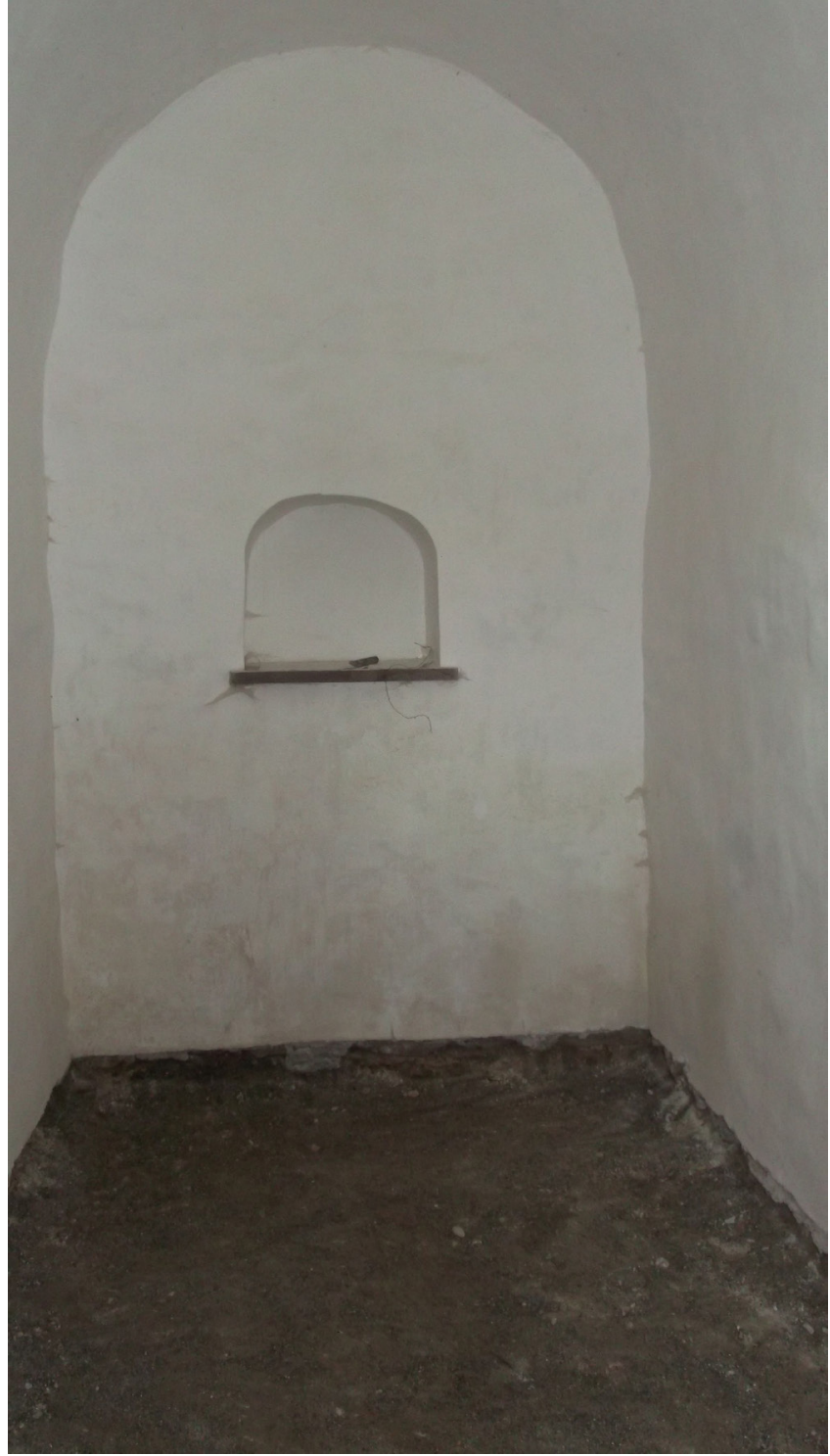

Fig. 7. Umezeala excesivă din interiorul camerelor aflate la parter fost adosat clădirii medievale un alt un corp care avea o subzidire cu beton.

Puţinele date istorice şi arheologice care au putut fi obţinute despre clisiarniţa Mănăstirii Probota sunt valoroase pentru că adaugă noi informaţii cu privire la acest edificiu important din orice mănăstire, în care se păstrau valori, dar şi documente ale lăcaşului sau primite spre păstrare de la terţi. Distrugerile care au afectat întregul ansamblu mănăstiresc s-au reflectat şi asupra turnului tezaur. Totuşi, cu toate transformările petrecute în timp, clisiarniţa a rămas singurul edificiu din incinta mănăstirii (cu excepţia bisericii) care a ajuns până astăzi. 


\section{ABREVIERI BIBLIOGRAFICE}

Analele Putnei

BOR

BCMI

BMI

RMI

SCIA, Artă plastică

SMIM
Analele Putnei, Sfânta Mănăstire Putna

Biserica Ortodoxă Română, București

Buletinul Comisiunii Monumentelor Istorice, București

Buletinul Monumentelor Istorice, București

Revista Monumentelor Istorice, București

Studii și Cercetări de Istoria Artei, Seria Artă Plastică, București

Studii şi Materiale de Istorie Medie, București

\section{BIBLIOGRAFIE}

\section{Surse}

DRH. A. Moldova, I, 1975 - Documenta Romaniae Historica, A. Moldova, I, eds. C. Cihodaru, I. Caproșu și L. Șimanschi, Editura Academiei, București.

Balan, T. 1939. Documente bucovinene, V, Editura Mitropolitul Silvestru, Cernăuţi.

Iorga, N. 1904. Studii și documente cu privire la istoria românilor. VI. Cărți domneşti, zapise şi răvaşe, partea II, Editura Socec, Bucureşti.

***, Acte oficiale. Consistoriul Superior Bisericesc. Sesiunea de primăvară. Biserica Ortodoxă Română, 36, $5-6,1913,1-272$.

\section{Literatură}

Balș, G. 1928. Bisericile și mănăstirile moldovenești din veacul al XVI-lea 1527-1582. Buletinul Comisiunii Monumentelor Istorice 21: 55-58.

Bătrîna, L. și Bătrîna, A. 1977. O primă ctitorie și necropolă voievodală datorată lui Ștefan cel Mare: Mănăstirea Probota. Studii și Cercetări de Istoria Artei, Seria Artă Plastică 24: 205-230.

Cantacuzino, Gh. I. 1997. Cercetări arheologice la Mănăstirea Probota-zona de vest a incintei. Revista Monumentelor Istorice 66, 1-2: 25-28.

Ghika-Budești, N. și Balș G. 1909. Mănăstirea Probota. București: Institutul de Arte Grafice Carol Göbl.

Gorovei, Șt. S. 2010. Contribuții prosografice și epigrafice. Studii și Materiale de Istorie Medie 28: 79-98.

Gorovei, Şt. S. 2014. Un nou izvor genealogic şi prosopografic: pomelnicul Mănăstirii Probota. Analele Putnei 10, 2: 287-312.

Iorga, N. 1905. Inscripţii din bisericile României, fascicula I. Bucureşti: Editura Minerva

Melchisedec, episcopul Romanului, 1885. Notiţe istorice şi arheologice adunate de pe la 48 de monastiri şi biserici antice din Moldova. Bucureşti: Tipografia Cărţilor Bisericeşti.

Lapedatu, Al. 1908. Serbarea de la Mănăstirea Probota (31 August 1908). Buletinul Comisiunii Monumentelor Istorice I: 135-136.

Nicolescu, C. 1954. Locuinţe domneşti în cuprinsul mănăstirilor în veacurile XV-XVII. Studii și Cercetări de Istoria Artei. Artă plastică 1, 3-4: 63-82.

Nicolescu, C. și Jipescu, F. 1956. Din trecutul Mănăstirii Probota. Studii și Cercetări de Istoria Artei. Artă plastică 3, 1-2: 292-298.

Puşcaşu, V. M. 2013. Mănăstirea Probota. Arheologie şi istorie. Suceava: Editura Karl A. Romstorfer.

Stoicescu, N. 1974. Repertoriul bibliografic al localităţilor şi monumentelor medievale din Moldova. București: Editura Academiei Române.

Șerban, I. 1999. Comisiunea Monumentelor Istorice (1892-1948). Inventar arhivă. Localități și monumente (A-Z). Dosare 1-3806. Legislație, activitate, organizare, colaborări externedosarele 3807-3885. Revista Monumentelor Istorice 68, 1-2: 1-197.

Tonellotto, A. și Valente, I. 2001. The Restauration of the Probota Monastery 1996-2001. Paris.

***1970, Cronică. Principalele lucrări de restaurare a monumentelor istorice din Republica Socialistă România, BMI 39, 1: 73-78.

***1933, Oficiale, BCMI 25, 76: 95-100. 


\section{LISTA ILUSTRAȚIEI}

Fig. 1. Mănăstirea Probota în anul 1909: turnul de la intrare, biserica și turnul clopotniță (după Ghika-Budești, Balș 1909)

Fig. 2. Ansamblul mănăstiresc Probota cu elementele componente în anul 1909 (după Ghika-Budești, Balș 1909)

Fig. 3. Cercetările arheologice în zona clisiarniței, campaniile 1994-2000 (după Pușcaşu 2013)

Fig. 4. Elemente de decorație a ferestrelor pe fațada sudică a turnului clopotniță

Fig. 5. Clisiarniţa Mănăstirii Probota a-1909 după Ghica-Budeşti, Balş, 1909, b-2019

Fig. 6. Aspectul fundației pe latura de vest

Fig. 7. Umezeala excesivă din interiorul camerelor aflate la parter

MONICA DEJAN

Muzeul Naţional al Bucovinei Suceava monicadejan@yahoo.com

ŞTEFAN DEJAN

Muzeul Naţional al Bucovinei Suceava stefandejan@gmail.com 